Provided for non-commercial research and education use. Not for reproduction, distribution or commercial use.

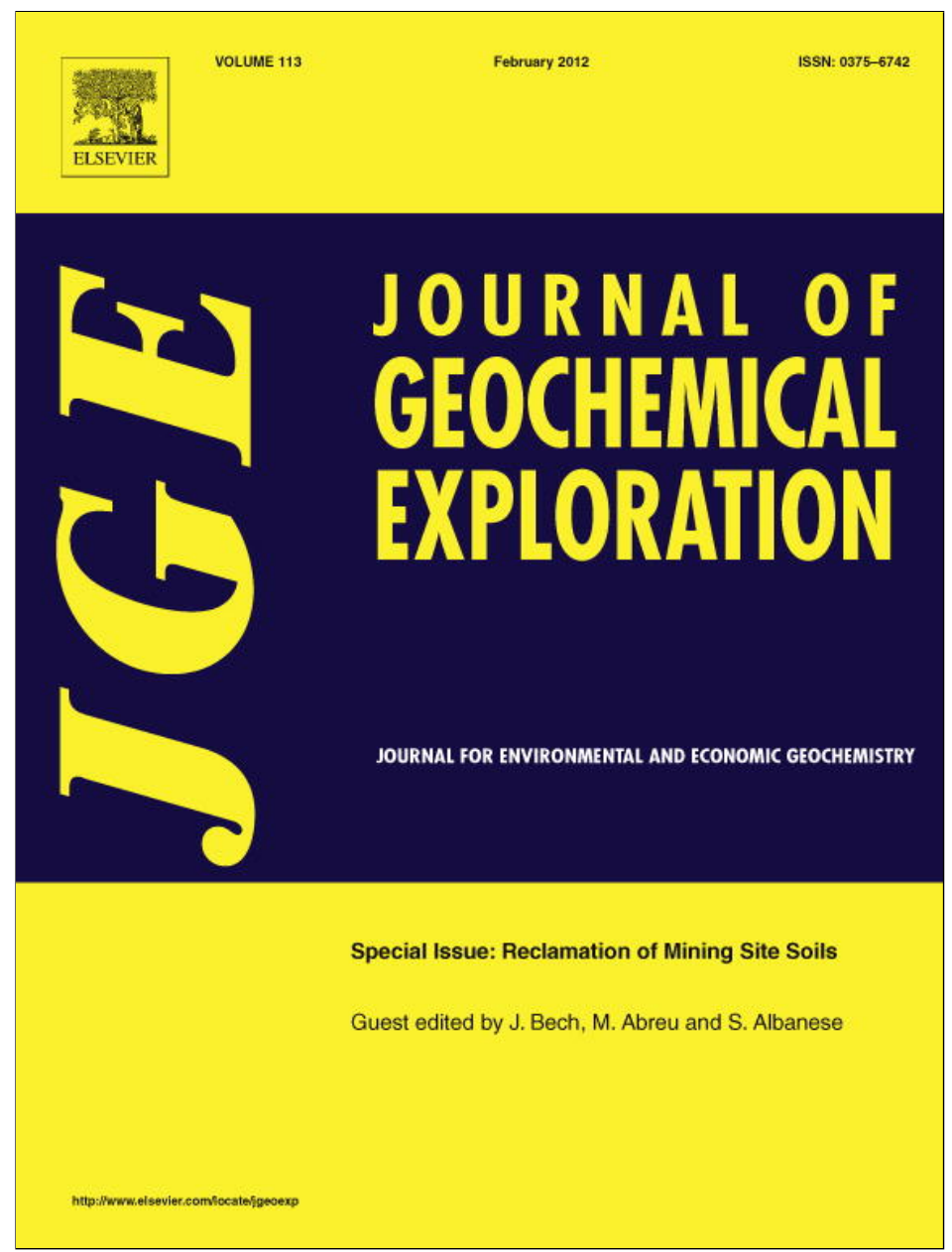

This article appeared in a journal published by Elsevier. The attached copy is furnished to the author for internal non-commercial research and education use, including for instruction at the authors institution and sharing with colleagues.

Other uses, including reproduction and distribution, or selling or licensing copies, or posting to personal, institutional or third party websites are prohibited.

In most cases authors are permitted to post their version of the article (e.g. in Word or Tex form) to their personal website or institutional repository. Authors requiring further information regarding Elsevier's archiving and manuscript policies are encouraged to visit:

http://www.elsevier.com/copyright 


\title{
Toxicity assessment of contaminated soils from a mining area in Northeast Italy by using lipid peroxidation assay
}

\author{
Mohammad Wahsha ${ }^{\text {a,*}}{ }$, Claudio Bini ${ }^{\text {a }}$, Silvia Fontana ${ }^{\text {a }}$, Abeer Wahsha ${ }^{\text {b }}$, Diana Zilioli ${ }^{\text {a }}$ \\ a Department of Environmental Sciences, Ca' Foscari University of Venice, Italy \\ b Department of Industrial Engineering, Jordan University for Science and Technology, Irbid, Jordan
}

\section{A R T I C L E I N F O}

\section{Article history:}

Received 30 September 2010

Accepted 16 September 2011

Available online 22 September 2011

\section{Keywords:}

Heavy metals

Taraxacum officinale

Salix spp.

Mining pollution

Lipid peroxidation

\begin{abstract}
A B S T R A C T
Contamination by heavy metals in soils may strongly affect the environmental quality. Lipid peroxidation caused by heavy metals in plants was investigated as a relevant bioassay of toxicity. Soils and wild plants (dandelion and willow) were collected from an abandoned mine area in northeast Italy, and the concentration of different heavy metals ( $\mathrm{Ni}, \mathrm{Cr}, \mathrm{Cu}, \mathrm{Pb}, \mathrm{Zn}$, Fe and $\mathrm{Mn}$ ) were measured and analyzed. Soils affected by mining activities presented total $\mathrm{Zn}, \mathrm{Cu}$, and $\mathrm{Pb}$ concentrations $\left(2566,3975,20,815 \mathrm{mg} \mathrm{kg}^{-1}\right.$ respectively) above toxic thresholds, and $58 \%$ for Fe. Heavy metal-induced oxidative stress was evidenced by the generation of reactive radicals, followed by an increase in malondialdehyde (MDA) production up to $41.64 \mu \mathrm{M}$ in willow leaves. We found that MDA concentration in plant tissues differed significantly among species and plant organs. The higher concentration of metal in soil corresponded with the higher concentration of MDA in the plant. The combined results of metal concentration, MDA content and translocation coefficients in plants show that the investigated plants are rather highly tolerant towards environmental pollution. This suggests that they could be useful in phytoremediation of metal contaminated sites.
\end{abstract}

(C) 2011 Elsevier B.V. All rights reserved.

\section{Introduction}

Contaminants such as heavy metals are threatening human health by their impact on ecosystems, water and food quality (Bini et al., 2010; Lim et al., 2008). Bioavailable heavy metals can enter the food chain through primary producers, reducing growth cycle and altering some biochemical pathways in plants (Loureiro et al., 2006). Moreover, heavy metals induce oxidative stress by generation of hydrogen peroxide, superoxide radical, hydroxyl radical and singlet oxygen, collectively termed reactive oxygen species (ROS) (Verma and Dubey, 2003). Many organic molecules are exposed to severe damage by free radicals after high accumulation of heavy metals in plants (Alfonso and Puppo, 2009; Joshi et al., 2005). Formation of ROS in cells is associated with the development of many pathological states (e. g. reduced root elongation, seed germination, signaling imbalance) (Bini et al., 2008; Wahsha and Al-Jassabi, 2009). This has contributed to the creation of the oxidative stress concept; in this view, ROS are unavoidable toxic products of $\mathrm{O}_{2}$ metabolism, and aerobic organisms have evolved antioxidant defenses to protect against this toxicity (Alfonso and Puppo, 2009). Oxidative stress can increase sharply in

Abbreviations: MDA, (Malondialdehyde); LPO, (Lipid peroxidation); TBA, (Thiobarbituric acid); TBARS, (Thiobarbituric acid reactive substances); ROS, (Reactive oxygen species); PUFA, (Polyunsaturated fatty acids).

* Corresponding author at: Department of Environmental Sciences, Dorsoduro, 2137, 30123 Venice, Italy. Tel.: + 39412348918 ; fax: + 39412348584.

E-mail address: m.wahsha@stud.unive.it (M. Wahsha). cells either due to the decrease in the activity of the antioxidant defense systems or to the overproduction of ROS (Mukherjee et al., 2007; Soffler, 2007). The most harmful effect induced by ROS in plants is the oxidative degradation of lipids, especially polyunsaturated fatty acids (PUFA) in cell membranes known as lipid peroxidation, which can directly cause biomembrane disorganization (Gobert et al., 2010; Timbrell, 2009; Wahsha et al., 2010). Several studies reported that ROS can initiate lipid peroxidation through the action of hydroxyl radicals (Armstrong, 2008; Katoch and Begum, 2003). Lipid peroxidation reactions are usually free radical-driven chain reactions in which one radical can induce the oxidation of PUFA (Abuja and Albertini, 2001). The lipid peroxide Malondialdehyde (MDA) is one of the major end-product of lipid peroxidation process (Yadav, 2010). In this case, membrane destabilization and fusion are directly correlated with MDA production (Wahsha and Al-Jassabi, 2009; Wahsha et al., 2010). The determination of MDA content is widely used as a reliable tool to detect the oxidative stress hazard by estimating the formation of lipid peroxides in biological material (Loureiro et al., 2006; Taulavuori et al., 2001; Zielinska et al., 2001). Furthermore, the formation of ROS and an increased MDA production were observed in plants exposed to different heavy metals as $\mathrm{Cr}, \mathrm{Pb}, \mathrm{Cu}$ and $\mathrm{Zn}$ under laboratory conditions (Aravind and Prasad, 2003; Baryla et al., 2000; Sinha et al., 2005; Verma and Dubey, 2003).

The objectives of this work were: i) to assess the concentration and bioavailability of the following metals: $\mathrm{Ni}, \mathrm{Cr}, \mathrm{Cu}, \mathrm{Pb}, \mathrm{Zn}, \mathrm{Fe}$ and $\mathrm{Mn}$ in soils and plants of a mining area, and ii) to apply the lipid peroxidation biotoxicity assay to wild plants growing on mine soils. 


\section{Materials and methods}

\subsection{Site description}

Field observations were carried out in the Imperina Creek watershed. The Imperina Valley is located in the mountain district of Belluno (North-east Italy), with an altitude ranging between $543 \mathrm{~m}$ and $990 \mathrm{~m}$ above sea level. The geological substrate consists of rocks of the metamorphic basement (Pre-Permian), in tectonic contact with dolomite rocks (Dolomia Principale, Upper Triassic). The mined area is located along the tectonic contact; it consists of a deposit of mixed sulfides, composed primarily of cupriferous pyrite, pyrite and chalcopyrite, with minor amounts of other metallic minerals (Frizzo and Ferrara, 1994). Full information on the geological and environmental setting is available in Giordano (2008) and Campana et al. (2007). The vegetation cover is mainly constituted of mixed forests (Abies alba Mill., Picea abies (L.) H. Karst., 1881, Fagus sylvatica L. and Ostrya carpinifolia Scop.), with clearances where herbaceous and shrubby vegetation prevails over the arboreal one (Dissegna et al., 1997). Mining activities took place in Imperina Valley from the 15 th century until 1962, when the mine was closed.

\subsection{Field sampling}

Before the sampling program was devised, preliminary investigations were carried out in 2008 in the mined area and the conterminous zone. Following the guidance on sampling techniques recommended by Margesin and Schinner (2005), eight sites (six contaminated soils and two control soils, site 7 on metamorphic basement and site 8 on dolomite) were selected according to different geo-morpho-pedological conditions, vegetation coverage and anthropogenic impact. Soils are mostly entisols (sites 1,2,3,4,5) and inceptisols (sites 6,7), while site 8 is a mollisol over dolomite. Pedoclimate conditions, however, are the same for all sites, with perudic soil moisture regime and mesic temperature regime. Full information on soil properties and classification is available in Fontana et al. (2010). Successively, all locations were sampled for topsoil and plants in the period between spring and summer 2009. A plant inventory was recorded following Pignatti (1982), and the relative abundances were estimated visually.

\subsubsection{Soil sampling}

According to the procedures described by Hood and Benton Jones (1997) and Margesin and Schinner (2005), soil samples were collected from the upper horizon at a depth of approximately $30 \mathrm{~cm}$. Each soil sample was a composite of 5-7 subsamples collected in a given sector $\left(4 \mathrm{~m}^{2}\right)$. Samples were taken at the site, mixed, packed in containers, and then transported to the laboratory. The samples were air dried at room temperature for 7-10 days, homogenized and sieved through a stainless-steel sieve of $2 \mathrm{~mm}$ mesh diameter before the determination of physico-chemical soil properties and quantification of soil heavy metal concentrations.

\subsubsection{Plant sampling}

Plant samples have been collected according to Benton Jones (2001) with some minor modifications. At least five specimens of selected plant species (at the early vegetative phase and normal morphological appearance) were sampled at each site with their corresponding soil clod (same pedoclimate). Samples were packed in plastic bags not completely closed with a non metallic closure, to allow gas exchange, and transported to the laboratory. Plant species were classified according to Pignatti (1982) as the following: common dandelion (Taraxacum officinale Weber ex F.H.Wigg. 1780), and different willows (Salix purpurea L., Salix caprea L., and Salix elaeagnos Scop.). All plants were gently washed with tap water, rinsed with distilled water and then divided into leaves, stems and roots. To remove moisture without causing appreciable thermal decomposition, samples were oven dried 2 days at $50{ }^{\circ} \mathrm{C}$ in the case of dandelions (Królak, 2003) and at $80^{\circ} \mathrm{C}$ for willows (Benton Jones, 2001). Dried plant tissues were ground into fine powder $(<100 \mu \mathrm{m})$ with an agate mill, and then stored for further analysis according to Benton Jones (2001).

\subsection{Analytical methods}

All chemicals used in this study were of analytical grade and purchased from Sigma-Aldrich Co., USA. Soil pH in water (1: 2.5) was measured potentiometrically following the protocol of Violante and Adamo (2000), organic carbon based on the method described by Walkley and Black (1934), cation exchange capacity (CEC) was analyzed following the method reported by Gessa and Ciavatta (2000), and soil particle size distribution was determined following the pipette method (Genevini et al., 1994). Soil samples preparation for heavy metals analysis: $0.2 \mathrm{~g}$ of the sieved soil sample was subjected to a complete digestion in a microwave (model 1600-Ethos, Milestone) in closed container made of Teflon. Based on Leita and Petruzzelli (2000), the breakdown was accomplished in $5 \mathrm{~mL}$ of aqua regia $\left(37 \% \mathrm{HCl}+65 \% \mathrm{HNO}_{3}, 1: 3\right)$ and $1 \mathrm{~mL}$ of $48 \%$ $\mathrm{HF}$, and then $1 \mathrm{~mL}$ of cold supersaturated $\mathrm{H}_{3} \mathrm{BO}_{3}$ was added. Two standard certified reference materials (Soil 5 from the International Atomic Energy Agency and MESS3 from National Research Council Canada) were analyzed as a part of the quality control. For plant samples, according to the procedure recommended by Jones (2001) and Fontana et al. (2010), $0.5 \mathrm{~g}$ of powder sample was digested in an acid mixture ( $5 \mathrm{~mL} 65 \% \mathrm{HNO}_{3}$ and $3 \mathrm{~mL} 30 \% \mathrm{H}_{2} \mathrm{O}_{2}$ ) in open vessels on a hot plate, followed by filtration with cellulose filter Wathman n.42 as described by Zang et al. (2002) and Jones (2001) with slight modifications. For both samples of soil and plants, the concentration of metals ( $\mathrm{Ni}, \mathrm{Cr}, \mathrm{Cu}, \mathrm{Pb}, \mathrm{Zn}, \mathrm{Fe}$ and $\mathrm{Mn}$ ) was determined by Inductively Coupled Plasma-Optical Emission Spectroscopy (ICP-OES) according to the method reported by Margesin and Schinner (2005).

\subsection{Estimation of lipid peroxidation (MDA content)}

For quality control and assurance for lipid peroxidation evaluation, 10 plant specimens were collected from not contaminated areas, in the university garden in the case of Taraxacum officinale, and from a natural area in a municipality in the province of Venice, in the case of Salix species. The MDA content was performed by the TBARS reaction with some modifications of the method of Heath and Packer (1968) by Taulavuori et al. (2001) and Ai-Jun et al. (2007). A $0.30 \mathrm{~g}$ fresh plant sample was homogenized in $20 \mathrm{~mL}$ solution of $0.25 \%$ thiobarbituric acid (TBA) in $10 \%$ trichloroacetic acid (TCA), using agate mortar and pestle. The homogenate mixture was incubated at $95^{\circ} \mathrm{C}$ for 30 min followed by quick cooling and centrifuged at $10,000 \mathrm{~g}$ for $10 \mathrm{~min}$. The absorbance of the clear supernatant was read spectrophotometrically at $532 \mathrm{~nm}$ using a spectrophotometer Hach DR 2000, and correction for unspecific turbidity was done by subtracting the absorbance of the sample at $600 \mathrm{~nm}$. A $20 \mathrm{ml}$ of $0.25 \%$ TBA in 10\% TCA was used as blank. The concentrations of lipid peroxides were quantified and expressed using Beer's law with an extinction coefficient of $155 \mathrm{mM}^{-1} \mathrm{~cm}^{-1}$.

\subsection{Statistical analysis procedure}

Statistical analysis was based on ANOVA and is presented as means \pm S.D. Statistical significance was considered at $p$-value of 0.05 or less. The data were analyzed statistically using Sigma Stat statistical software version 3.5. 
Table 1

Selected chemophysical properties of the studied soils. All data expressed as mean values \pm S.D $(\mathrm{n}=3)$. Sampling sites 7 and 8 are not contaminated.

\begin{tabular}{|c|c|c|c|c|c|c|}
\hline \multirow[t]{2}{*}{$\begin{array}{l}\text { Sampling } \\
\text { site }\end{array}$} & \multirow{2}{*}{$\begin{array}{l}\mathrm{pH} \\
\text { (In water } 1: 2.5)\end{array}$} & \multirow{2}{*}{$\begin{array}{l}\mathrm{CEC}^{\mathrm{a}} \\
\overline{\left(\mathrm{cmol}_{\mathrm{c}} \mathrm{kg}^{-1}\right)}\end{array}$} & \multirow{2}{*}{$\begin{array}{l}\text { Organic carbon } \\
\left(\mathrm{g} \mathrm{kg}^{-1}\right) \\
\end{array}$} & \multicolumn{3}{|c|}{$\begin{array}{l}\text { Particle size } \\
\text { distribution\% }\end{array}$} \\
\hline & & & & Sand & Silt & Clay \\
\hline 1 & $4.5 \pm 0.50$ & $10.4 \pm 1.1$ & $5 \pm 0.50$ & 40 & 46 & 14 \\
\hline 2 & $7.8 \pm 0.10$ & $15.5 \pm 0.90$ & $12 \pm 0.50$ & 46 & 43 & 11 \\
\hline 3 & $7.5 \pm 0.30$ & $9.0 \pm 0.39$ & $8 \pm 0.40$ & 71 & 25 & 4 \\
\hline 4 & $5.3 \pm 0.30$ & $5.8 \pm 0.65$ & $4 \pm 0.70$ & 41 & 53 & 6 \\
\hline 5 & $7.3 \pm 0.10$ & $23.8 \pm 2.10$ & $41 \pm 0.30$ & 68 & 27 & 5 \\
\hline 6 & $7.6 \pm 0.10$ & $11.0 \pm 0.78$ & $8 \pm 0.40$ & 44 & 46 & 10 \\
\hline 7 & $5.3 \pm 0.10$ & $14.4 \pm 1.81$ & $22 \pm 0.80$ & 61 & 29 & 10 \\
\hline 8 & $7.7 \pm 0.20$ & $34.3 \pm 2.40$ & $33 \pm 0.60$ & 15 & 69 & 16 \\
\hline
\end{tabular}

a Cation exchange capacity (CEC).

\section{Results and discussion}

\subsection{Chemophysical properties of soil samples}

Selected soil variables ( $\mathrm{pH}, \mathrm{CEC}$, organic carbon content and soil particle size distribution) were analyzed in all soil samples and a summary of these analyses is given in Table 1. Many characteristics of the studied soils vary; for example, the $\mathrm{pH}$ values oscillate from about 4 to nearly 8 , due to the nature of the soil parent material; the highly acidic $\mathrm{pH}$ value found in site 4 soil is probably due to weathering oxidation of iron sulfides (pyrite and chalcopyrite) in the soil (Bini, in press; Delgado et al., 2009). Another parameter in the table is the CEC which has shown generally low values for all the soil samples (from 5.8 to $23.8 \mathrm{cmol}_{\mathrm{C}} \mathrm{kg}^{-1}$ ), except for the soils developed on dolomite $\left(34.3 \mathrm{cmol}_{\mathrm{C}} \mathrm{kg}^{-1}\right.$, site 8$)$. Moreover, the organic carbon content is generally lower in the mine soils than in controls $(7,8)$, with exception of soil from site 5 . The soils' texture are loamy (site $1,2,6$ ), sandy-loam (site $3,5,7$ ) or silty-loam (site 4,8 ) according to the Soil Survey Staff (1999).

Table 2 summarizes the results of the average concentrations of $\mathrm{Ni}, \mathrm{Cr}, \mathrm{Cu}, \mathrm{Pb}, \mathrm{Zn}, \mathrm{Fe}$ and $\mathrm{Mn}$ in the soils tested. The total concentrations of most of the investigated metals $(\mathrm{Cu}, \mathrm{Pb}, \mathrm{Zn}$ and $\mathrm{Fe})$ in the soil samples were significantly higher (ANOVA $p<0.05$ ) than those of control, and above the toxicity threshold according to Italian legislation (D.L. 152/2006). Cu, $\mathrm{Pb}$ and $\mathrm{Zn}$ concentrations recorded at site 8 , although they overcome the Italian threshold limits for residential areas, are related to the geochemistry of the parent material (mainly dolomite). Data reported in Table 2 show that the studied area is not contaminated by $\mathrm{Cr}$ and $\mathrm{Ni}$, given their absence in the ore minerals (Bini, in press).

The linear correlation between $\mathrm{Pb}, \mathrm{Cu}, \mathrm{Zn}(\mathrm{Cu} / \mathrm{Pb} 0.768 ; \mathrm{Pb} / \mathrm{Zn}$ 0.709 , significant at $\mathrm{p}<0.05$ ) is consistent with their calcophilous behavior, since these metals tend to form compounds with sulfur, as chalcopyrite $\left(\mathrm{CuFeS}_{2}\right)$, sphalerite $(\mathrm{ZnS})$ and galena $(\mathrm{PbS})$, commonly found in the Imperina Valley ore deposits (Frizzo and Ferrara, 1994). Ni and $\mathrm{Cr}$ are negatively correlated with $\mathrm{Cu}(-0.796$; $-0.680), \mathrm{Pb}(-0.893 ;-0.526)$ and $\mathrm{Zn}(-0.750 ;-0.758)$. Conversely, a positive correlation is seen between $\mathrm{Cr}$ and $\mathrm{Zn}$. Fe and $\mathrm{Mn}$ are not significantly correlated with any other element, although they share the same geochemical, as a result of anthropogenic activities in the area (Bradl, 2005).

\subsection{Heavy metal accumulation in plants}

The concentrations of heavy metals in plant species of Imperina Valley are presented in Table 3. Willow plants (genus Salix) accumulated significant quantities of heavy metals in both leaves and roots, irrespective of the species. Dandelion plants (genus Taraxacum) accumulated $\mathrm{Cu}, \mathrm{Pb}, \mathrm{Zn}, \mathrm{Fe}$ and $\mathrm{Mn}$ in leaves, and the obtained results are in agreement with data from literature, (Savinov et al., 2007; Simon et al., 1996). Instead, $\mathrm{Ni}$ and $\mathrm{Cr}$ present concentrations below the phytotoxicity threshold reported by Kabata-Pendias (2001); this is consistent with concentration levels recorded in the soil (Table 2). Mn concentrations are within the "normal" values (Kabata-Pendias, 2001) for all samples. Fe concentrations in plants showed a large range of variation: between 67 and $926 \mathrm{mg} \mathrm{kg}^{-1}$ in willow, and up to $1636 \mathrm{mg} \mathrm{kg}^{-1}$ in dandelion. However, this metal is not considered toxic unless at very high concentration above $1000 \mathrm{mg} \mathrm{kg}^{-1}$ according to Kabata-Pendias (2011). Cu concentrations in both leaves and roots of willow are above the toxicity threshold (Kabata-Pendias, 2001), while in the stem, the Cu concentrations are relatively low, except in S. caprea. Willows proved to have the ability to accumulate $\mathrm{Pb}$ in roots more than in the aerial parts, and in the leaves more than in the stems, with the exception of $S$. purpurea, where $\mathrm{Pb}$ is accumulated in leaves (Table 3). Regarding Zn, our results show that the highest concentrations are recorded in Salix leaves, and decrease gradually from stems to roots, counteracting the $\mathrm{Pb}$ concentration trend. $\mathrm{Zn}$ concentrations in Salix exceed the toxicity level recommended by

Table 2

Concentration of metals in soils of Imperina Valley. Ni, Cr, Cu, Pb, $\mathrm{Zn}$ and $\mathrm{Mn}$ are expressed as $\mathrm{mg} \mathrm{kg}^{-1}$, Fe as percentage. All the values are mean of five replicates \pm S.D.

\begin{tabular}{|c|c|c|c|c|c|c|c|}
\hline $\begin{array}{l}\text { Sampling } \\
\text { site: }\end{array}$ & $\mathrm{Ni}$ & $\mathrm{Cr}$ & $\mathrm{Cu}$ & $\mathrm{Pb}$ & $\mathrm{Zn}$ & $\mathrm{Fe}$ & Mn \\
\hline 1 & $<\mathrm{DL}^{\mathrm{d}}$ & $<\mathrm{DL}^{\mathrm{d}}$ & $3726 \pm 21$ ii & $20,815 \pm 93$ ii & $1554 \pm 18$ ii & $53 \pm 0.3 \mathrm{ii}$ & $178 \pm 2 \mathrm{ji}$ \\
\hline 2 & $<\mathrm{DL}^{\mathrm{d}}$ & $22 \pm 1$ ii & $3367 \pm 42$ ii & $14,635 \pm 71$ ii & $1188 \pm 8$ ii & $32 \pm 0.3 \mathrm{ii}$ & $280 \pm 1 \mathrm{ji}$ \\
\hline 3 & $60 \pm 1 \mathrm{ii}$ & $102 \pm 1$ ii & $526.4 \pm 2.8 \mathrm{ii}$ & $228 \pm 5 \mathrm{ij}$ & $472 \pm 3 \mathrm{ij}$ & $6 \pm 0.1 \mathrm{ji}$ & $1166 \pm 6 \mathrm{ii}$ \\
\hline 4 & $<\mathrm{DL}^{\mathrm{d}}$ & $<\mathrm{DL}^{\mathrm{d}}$ & $3975 \pm 18 \mathrm{ii}$ & $14,619 \pm 87 \mathrm{ii}$ & $2423 \pm 21$ ii & $58 \pm 0.4 \mathrm{ii}$ & $175 \pm 3$ ii \\
\hline 5 & $47 \pm 2 \mathrm{ii}$ & $93 \pm 1 \mathrm{ii}$ & $500 \pm 3 \mathrm{ij}$ & $294 \pm 4 \mathrm{ij}$ & $431 \pm 2 \mathrm{ij}$ & $5 \pm 0.0 \mathrm{ji}$ & $1140 \pm 7 \mathrm{ii}$ \\
\hline 6 & $<\mathrm{DL}^{\mathrm{d}}$ & $<\mathrm{DL}^{\mathrm{d}}$ & $2334 \pm 19$ ii & $11,668 \pm 67$ ii & $2566 \pm 37 \mathrm{ii}$ & $48 \pm 0.4 \mathrm{ii}$ & $161 \pm 2 \mathrm{jj}$ \\
\hline 7 & $58 \pm 1$ & $162 \pm 2$ & $98 \pm 2$ & $52 \pm 5$ & $103 \pm 2$ & $4 \pm 0.6$ & $1025 \pm 17$ \\
\hline 8 & $14 \pm 1$ & $33 \pm 1$ & $283 \pm 8$ & $343 \pm 5$ & $576 \pm 9$ & $1 \pm 0.0$ & $193 \pm 1$ \\
\hline It. $A v^{1, a}$ & 46 & 100 & 51 & 21 & 89 & 4 & 900 \\
\hline Int. $A v^{2, a}$ & 40 & 200 & 20 & 10 & 50 & - & 850 \\
\hline E.V ${ }^{3, a}$ & 100 & 100 & 100 & 100 & 250 & - & 1500 \\
\hline R.L ${ }^{4, b}$ & 120 & 150 & 120 & 100 & 150 & - & - \\
\hline I.L $5, b$ & 500 & 800 & 600 & 1000 & 1500 & - & - \\
\hline Mess $3,^{c}$ & $49 \pm 1$ & $116 \pm 1$ & $39 \pm 1$ & $<\mathrm{DL}^{\mathrm{d}}$ & $157 \pm 1$ & $5 \pm 0$ & $310 \pm 3$ \\
\hline C.C.M $3^{6, c}$ & $47 \pm 2$ & $105 \pm 4$ & $34 \pm 2$ & $21 \pm 1$ & $159 \pm 8$ & $4 \pm 0$ & $324 \pm 12$ \\
\hline Soil $5^{3}$ & $12 \pm 1$ & $27 \pm 1$ & $80 \pm 1$ & $174 \pm 4$ & $366 \pm 6$ & $5 \pm 1$ & $890 \pm 18$ \\
\hline S.S.C $5^{7, c}$ & - & $29 \pm 3$ & $77 \pm 5$ & $129 \pm 26$ & $368 \pm 8$ & $5 \pm 1$ & $852 \pm 37$ \\
\hline
\end{tabular}

${ }^{1}$ Italian average, ${ }^{2}$ International average, ${ }^{3}$ Excessive values, ${ }^{4}$ Residential Limits, ${ }^{5}$ Industrial Limits, ${ }^{6}$ Certified composition of Mess $3,{ }^{7}$ Certified composition of Soil, ${ }^{\text {Reference average }}$ values (adopted from Angelone and Bini, 1992), ${ }^{\mathrm{b}}$ Threshold limits in the Italian legislation (D.L. 152/2006, Annex 5), ${ }^{\mathrm{C}}$ Certified reference material, ${ }^{\mathrm{d}}$ Less than the detection limit. The two letter symbols following \pm S.D within the same column indicate if there is a significant difference or not when compared to control sites 7 and 8 respectively. i indicates significant difference at $\mathrm{p}<0.05$ and $\mathrm{j}$ indicates no significant difference according to ANOVA. 
Table 3

Concentration of heavy metals in Salix and Taraxacum tissues ( $\mathrm{mg} \mathrm{kg}^{-1} \mathrm{dry}$ weight). All the values are mean of five replicates \pm S.D.

\begin{tabular}{|c|c|c|c|c|c|c|c|c|c|}
\hline Site & Plant & & $\mathrm{Ni}$ & $\mathrm{Cr}$ & $\mathrm{Cu}$ & $\mathrm{Pb}$ & $\mathrm{Zn}$ & $\mathrm{Fe}$ & Mn \\
\hline \multirow[t]{6}{*}{3} & Salix eleagnos & $\mathrm{L}^{\mathrm{b}}$ & $4.75 \pm 0.29$ & $3.33 \pm 0.29$ & $27.83 \pm 0.14$ & $26.4 \pm 2$ & $517 \pm 3$ & $570 \pm 6$ & $70 \pm 0.7$ \\
\hline & & $S^{c}$ & $<\mathrm{DL}^{\mathrm{a}}$ & $2.84 \pm 0.24$ & $16 \pm 1$ & $7.2 \pm 1.6$ & $388 \pm 3$ & $67 \pm 0.5$ & $17 \pm 0.1$ \\
\hline & & $\mathrm{R}^{\mathrm{d}}$ & $3.68 \pm 0.25$ & $3.15 \pm 0.15$ & $81 \pm 1$ & $32.7 \pm 2.1$ & $228 \pm 2$ & $427 \pm 3$ & $26.5 \pm 0.2$ \\
\hline & Salix purpurea & $\mathrm{L}^{\mathrm{b}}$ & $<\mathrm{DL}^{\mathrm{a}}$ & $3.69 \pm 0.23$ & $28 \pm 0.3$ & $25.6 \pm 1.2$ & $232 \pm 1$ & $661 \pm 3$ & $81.8 \pm 1$ \\
\hline & & $S^{c}$ & $<\mathrm{DL}^{\mathrm{a}}$ & $2.66 \pm 0.20$ & $14.12 \pm 0.14$ & $<\mathrm{DL}^{\mathrm{a}}$ & $190 \pm 1$ & $79 \pm 0.35$ & $19.7 \pm 0.1$ \\
\hline & & $\mathrm{R}^{\mathrm{d}}$ & $<\mathrm{DL}^{\mathrm{a}}$ & $3.03 \pm 0.28$ & $15.82 \pm 0.17$ & $<\mathrm{DL}^{\mathrm{a}}$ & $93 \pm 1$ & $217 \pm 1$ & $34.8 \pm 0.2$ \\
\hline \multirow[t]{3}{*}{4} & Salix caprea & $\mathrm{L}^{\mathrm{b}}$ & $<\mathrm{DL}^{\mathrm{a}}$ & $3.71 \pm 0.17$ & $39.88 \pm 0.18$ & $156.2 \pm 2$ & $339 \pm 1$ & $927 \pm 6$ & $104.5 \pm 0.4$ \\
\hline & & $S^{c}$ & $10.65 \pm 0.48$ & $2.39 \pm 0.32$ & $50.22 \pm 0.23$ & $99.4 \pm 2.8$ & $240 \pm 1$ & $122 \pm 1$ & $10.9 \pm 0.1$ \\
\hline & & $\mathrm{R}^{\mathrm{d}}$ & $<\mathrm{DL}^{\mathrm{a}}$ & $2.89 \pm 0.08$ & $55.51 \pm 0.77$ & $573.1 \pm 18.7$ & $156 \pm 1$ & $650 \pm 3$ & $13.4 \pm 0.1$ \\
\hline 2 & Taraxacum officinale & $\mathrm{L}^{\mathrm{b}}$ & $<\mathrm{DL}^{\mathrm{a}}$ & $3.51 \pm 0.26$ & $42.73 \pm 0.46$ & $78.8 \pm 3.6$ & $79 \pm 1$ & $1068 \pm 1.27$ & $16.6 \pm 1$ \\
\hline 6 & Taraxacum officinale & $\mathrm{L}^{\mathrm{b}}$ & $<\mathrm{DL}^{\mathrm{a}}$ & $<\mathrm{DL}^{\mathrm{a}}$ & $53.88 \pm 0.45$ & $129 \pm 3$ & $160 \pm 1$ & $1636 \pm 6$ & $88 \pm 1$ \\
\hline
\end{tabular}

a Below detection limit.

b Leaves.

c Stem.

d Root.

Kabata-Pendias (2001). Moreover, S. purpurea presents lower concentrations for the elements $\mathrm{Cu}, \mathrm{Pb}, \mathrm{Zn}$, than $S$. caprea and especially $S$. eleagnos.

It is noteworthy to point out, however, that willows' ability to accumulate heavy metals in different parts is independent of the species; rather, it depends on local factors as soil and pedoclimate (particularly temperature, aeration and water content) and on plant physiology and aging (Baker and Brooks, 1989; Mikulka et al., 2009). Moreover, a counteracting behavior of essential and toxic heavy metals is likely to occur as a barrier effect of the roots (Fontana et al., 2010).

Concerning Taraxacum (plants), data on heavy metals in roots are not available and therefore only heavy metal concentrations in leaves are reported in Table 3. Data show that this plant is able to accumulate $\mathrm{Cu}$ and $\mathrm{Pb}$ in leaves at concentrations above the toxicity threshold indicated by Kabata-Pendias (2001). Zn levels were within the normal range (27-150 $\mathrm{mg} \mathrm{kg}^{-1}$ ) given by Kabata-Pendias (2001), in Taraxacum leaves from site $4\left(79 \mathrm{mg} \mathrm{kg}^{-1}\right)$ while plants from site 6 present the $\mathrm{Zn}$ concentration slightly above the normal values (160 $\mathrm{mg} \mathrm{kg}^{-1}$ ).

We have calculated also the translocation factor of willows species (ratio between heavy metal concentration in leaves and in roots). Salix translocate and retain heavy metals in the aerial parts, in particular Zn (S. eleagnos $\mathrm{TF}_{\mathrm{Zn}}=2.27 ;$ S. purpurea $\mathrm{TF}_{\mathrm{Zn}}=2.5 ;$ S. caprea $\left.\mathrm{TF}_{\mathrm{Zn}}=2.18\right)$. Instead, $\mathrm{Pb}$ and $\mathrm{Cu}$ are scarcely translocated $\left(\mathrm{TF}_{\mathrm{Pb}}=0.81\right.$ in S. eleagnos; 0.27 in $S$. caprea; $\mathrm{TF}_{\mathrm{Cu}}=0.34$ in S. eleagnos; 0.72 in $S$. caprea), owing to the root barrier effect. However, S. purpurea seems to be more prone to transfer $\mathrm{Pb}$ and $\mathrm{Cu}$ ( $\mathrm{TF}_{\mathrm{Pb}}$ not computable; $\mathrm{TF}_{\mathrm{Cu}}=1.76$ ).

Translocation factors calculated for Salix samples suggest that heavy metals present different mobility within the plant. The less mobile among them is $\mathrm{Pb}$ (average $\mathrm{TF}=0.54$ ), which tends to be blocked in the root part, indicating that this chemical element is unessential for plants, and suggesting some exclusion mechanism by plants. Mn, $\mathrm{Zn}$ and Fe appear to be the most translocated among the elements

Table 4

The contents of MDA of $T$. officinale from different sites in Imperina Valley. Data represent mean values \pm S.D based on three independent determinations.

\begin{tabular}{|c|c|c|c|}
\hline \multirow[t]{2}{*}{ Group } & \multicolumn{2}{|c|}{ MDA concentration $(\mu \mathrm{M})$} & \multirow{2}{*}{$\frac{\text { Significance effect }}{\text { (p-value) }}$} \\
\hline & Leaves & Roots & \\
\hline Control & $2.859 \pm 0.18$ & $2.012 \pm 0.07$ & 0.290 \\
\hline Site 1 & $14.709 \pm 3.06$ & $8.826 \pm 0.67$ & 0.002 \\
\hline Site 2 & $7.147 \pm 0.52$ & $6.645 \pm 1.14$ & 0.001 \\
\hline Site 3 & $6.301 \pm 1.10$ & $5.079 \pm 0.42$ & 0.001 \\
\hline Site 4 & $7.618 \pm 1.10$ & $9.742 \pm 2.20$ & 0.002 \\
\hline Site 5 & $3.372 \pm 1.78$ & $10.366 \pm 2.28$ & 0.001 \\
\hline Site 6 & $7.521 \pm 2.24$ & $11.324 \pm 1.82$ & 0.001 \\
\hline
\end{tabular}

considered (average $\mathrm{TF}=2.53,2.32$ and 1.93 , respectively), while $\mathrm{Cr}$ and $\mathrm{Cu}$ have similar concentrations in leaves and roots (average $\mathrm{TF} \approx 1$ ). Concerning $\mathrm{Ni}$, no translocation data are available, since most Ni concentrations are below the detection limits (see Table 3).

The metal translocation capacity combined with rapid growth and a higher biomass than herbaceous plants, nominate willows as good candidates for phytoremediation of polluted soils, consistently with what was stated by Greger and Landberg (2003).

\subsection{Lipid peroxidation quantification}

The LPO levels (expressed as MDA contents) in T. officinale (see Table 4) vary proportionally with the level of heavy metals in soils of the corresponding site (see Table 2), as it was observed by calculating the coefficient of determination $\left(\mathrm{R}^{2}\right)$ between the variables considered. $\mathrm{R}^{2}$ explains how much of the variability of MDA content in plants is correlated to metal concentration in soil (Fig. 1). In particular, $\mathrm{Pb}$ and $\mathrm{Zn}$ concentrations in soils and MDA contents in leaves present nearly similar patterns (Fig. 2), indicating a close relationship between MDA and metals, thus confirming the LPO test to be effective in environmental contamination assessment.

The control plants of $T$. officinale exhibited normal levels of LPO, and it was $0.2063 \mu \mathrm{M}$ in leaves and $0.1450 \mu \mathrm{M}$ in roots. There was a dramatic increase in MDA level in leaves and root homogenate from

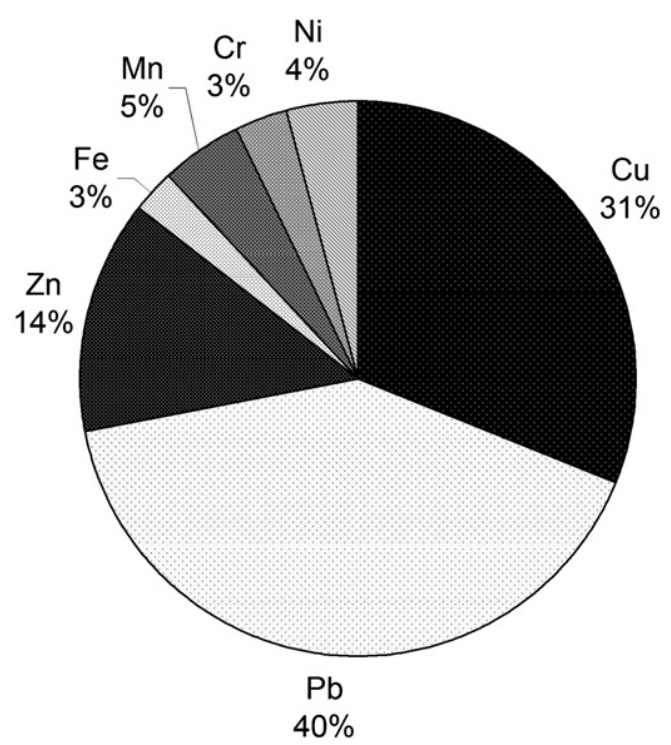

Fig. 1. Coefficient of determination $\left(\mathrm{R}^{2}\right)$ between metal concentration in soil and MDA content in plants of interest. 
A
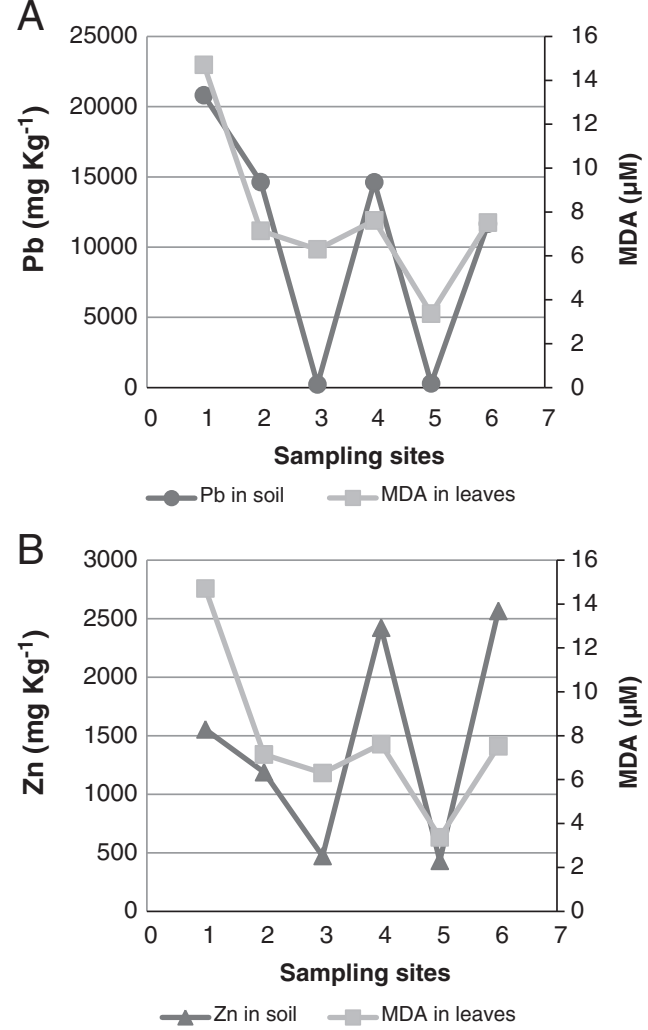

Fig. 2. Concentration of two metals of interest (A) $\mathrm{Pb}$; (B) $\mathrm{Zn}$ in topsoils and MDA concentration in leaves of Taraxacum officinale. Six sampling sites are considered.

T. officinale collected from Imperina Valley (Table 4). The contents of MDA were maximum in plant roots from site 6 and in leaves from site 1, indicating enhanced LPO compared to controls, and intermediate in plant samples from site $2,3,4$, and 5 . This agrees with data on

Table 5

The contents of MDA in leaves, stem and roots of willows from different sites in Imperina Valley. All the values are mean of three replicates \pm S.D.

\begin{tabular}{|c|c|c|c|c|}
\hline \multirow[t]{2}{*}{ Sample } & \multicolumn{3}{|c|}{ MDA concentration $(\mu \mathrm{M})$} & \multirow{2}{*}{$\begin{array}{l}\text { Significance effect } \\
\text { (p-value) }\end{array}$} \\
\hline & Root & Stem & Leave & \\
\hline \multicolumn{5}{|l|}{ Site 1} \\
\hline S. purpurea & $30.42 \pm 0.30$ & $18.70 \pm 0.51$ & $41.64 \pm 0.12$ & 0.002 \\
\hline S. caprea & $\mathrm{NC}^{\mathrm{a}}$ & $\mathrm{NC}^{\mathrm{a}}$ & $\mathrm{NC}^{\mathrm{a}}$ & \\
\hline S. elaeagnos & $29.50 \pm 0.54$ & $30.10 \pm 0.47$ & $37.00 \pm 0.09$ & 0.011 \\
\hline \multicolumn{5}{|l|}{ Site 2} \\
\hline S. purpurea & $\mathrm{NC}^{\mathrm{a}}$ & $\mathrm{NC}^{\mathrm{a}}$ & $\mathrm{NC}^{\mathrm{a}}$ & \\
\hline S. caprea & $\mathrm{NC}^{\mathrm{a}}$ & $\mathrm{NC}^{\mathrm{a}}$ & $\mathrm{NC}^{\mathrm{a}}$ & \\
\hline S. elaeagnos & $27.00 \pm 0.85$ & $35.44 \pm 0.10$ & $40.00 \pm 0.90$ & 0.001 \\
\hline \multicolumn{5}{|l|}{ Site 3} \\
\hline S. purpurea & $30.78 \pm 0.75$ & $31.04 \pm 0.26$ & $33.04 \pm 0.31$ & 0.007 \\
\hline S. caprea & $\mathrm{NC}^{\mathrm{a}}$ & $\mathrm{NC}^{\mathrm{a}}$ & $\mathrm{NC}^{\mathrm{a}}$ & \\
\hline S. elaeagnos & $24.92 \pm 0.51$ & $24.36 \pm 0.77$ & $26.94 \pm 0.02$ & 0.001 \\
\hline \multicolumn{5}{|l|}{ Site 4} \\
\hline S. purpurea & $25.30 \pm 0.66$ & $27.80 \pm 0.81$ & $28.40 \pm 0.92$ & 0.001 \\
\hline S. caprea & $29.45 \pm 0.32$ & $28.90 \pm 0.22$ & $31.74 \pm 0.14$ & 0.032 \\
\hline S. elaeagnos & $\mathrm{NC}^{\mathrm{a}}$ & $\mathrm{NC}^{\mathrm{a}}$ & $\mathrm{NC}^{\mathrm{a}}$ & \\
\hline \multicolumn{5}{|l|}{ Site 5} \\
\hline S. purpurea & $\mathrm{NC}^{\mathrm{a}}$ & $\mathrm{NC}^{\mathrm{a}}$ & $\mathrm{NC}^{\mathrm{a}}$ & \\
\hline S. caprea & $20.37 \pm 0.74$ & $24.80 \pm 0.38$ & $27.50 \pm 0.33$ & 0.004 \\
\hline S. elaeagnos & $19.90 \pm 0.55$ & $24.51 \pm 0.03$ & $28.70 \pm 0.94$ & 0.001 \\
\hline \multicolumn{5}{|l|}{ Control } \\
\hline S. purpurea & $20.47 \pm 0.64$ & $18.70 \pm 0.34$ & $23.08 \pm 1.10$ & 0.127 \\
\hline S. caprea & $18.40 \pm 0.41$ & $18.10 \pm 0.70$ & $20.32 \pm 0.52$ & 0.053 \\
\hline S. elaeagnos & $19.20 \pm 0.90$ & $18.21 \pm 1.20$ & $24.10 \pm 0.82$ & 0.410 \\
\hline
\end{tabular}

\footnotetext{
a Sample not collected.
}

soil pollution (Table 2). Using Kruskal-Wallis one way analysis of variance on ranks we could find statistically significant differences $(\mathrm{p}<0.05)$ in the average MDA contents among plants from different sites compared with those of the control group.

In agreement with previous results by Savinov et al. (2007), the increase of MDA production in T. officinale was expected because when heavy metal levels increase in soil their absorption by roots will increase, and the lipid peroxidation through the possible excessive generation of free radicals will be incremented. T. officinale responds to the increased heavy metal contents by intensification of LPO processes, which are related to the concentrations of $\mathrm{Cu}, \mathrm{Zn}, \mathrm{Pb}$ and Fe in the soil, as a result of an imbalance in the homeostasis of the antioxidant defense system (Alfonso and Puppo, 2009).

Lipid peroxidation in leaves, stems and roots of willows, measured as MDA content, are given in Table 5. Compared to control, heavy metals induced oxidative stress in willows was evident from the increased lipid peroxidation in roots, stems and leaves, indicating an enhanced MDA production, with MDA increasing in leaves in comparison to roots and stems. This is in agreement with data reported by Kuzovkina et al. (2004) and Ali et al. (2003). A maximum concentration of $41.64 \mu \mathrm{M}$ MDA in S. purpurea leaves collected from site 1 and $30.78 \mu \mathrm{M}$ in the roots of the same species from site 3 was observed, indicating severe cell injury (Maleci, 2011, personal communication). Generally, in both parts of the plant, the MDA contents were found to be positively correlated with metal accumulation $(p<0.05)$. The high level of MDA observed in investigated plants under metal stress might be attributed to the peroxidation of membrane lipids caused by ROS due to metal stress indicating a concentration-dependent free radical generation (Ali et al., 2003; Bini et al., 2010).

\section{Conclusions}

In this study, the soils in the mining area are highly contaminated by trace elements, mainly $\mathrm{Cu}, \mathrm{Zn}, \mathrm{Pb}$ and $\mathrm{Fe}$. The observed ability of Salix species and T. officinale to continue growth in the presence of heavy metals and to accumulate metals in their tissues, and particularly in leaves, demonstrated their tolerance to moderate to high levels of metals. Therefore, they have good potential to be used in phytoremediation projects. Our results show that $T$. officinale, S. purpurea, S. caprea and S. elaeagnos exposed to great metal concentrations in soils result in an increment in LPO in their tissues, suggesting an important role of oxidative stress in the pathogenesis of heavy metal-induced cellular toxicity, and they can be a promising bioindicator for such research. The LPO process proved to be a useful tool for health assessment of wild-growing plant species, as it reflects the anthropic heavy metal pollution in ecosystems.

\section{Acknowledgments}

We are very grateful to two anonymous reviewers for their valuable suggestions and comments that improved the quality of this work.

\section{References}

Abuja, P., Albertini, R., 2001. Methods for monitoring oxidative stress, lipid peroxidation and oxidation resistance of lipoproteins. Clinica Chimica Acta 306, 1-17.

Ai-Jun, L., Xu-Hong, Z., Mei-Mei, C., Qing, C., 2007. Oxidative stress and DNA damages induced by cadmium accumulation. Journal of Environmental Sciences 19, 596-602.

Alfonso, D.L., Puppo, A., 2009. Reactive oxygen species in plant signaling. In: Baluška, F., Vivanco, J. (Eds.), Signaling and Communication in Plants. Springer, Heidelberg, pp. 175-190.

Ali, M.B., Vajpayee, P., Tripathi, R.D., Ria, U.N., Singh, S.N., Singh, S.P., 2003. Phytoremediation of lead, nickel, and copper by Salix acmophylla Boiss: role of antioxidant enzymes and antioxidant substances. Bulletin of Environmental Contamination and Toxicology 70, 462-469. 
Angelone, M., Bini, C., 1992. Trace elements concentrations in soils and plants of Western Europe. In: Adriano, D.C. (Ed.), Biogeochemistry of trace metals. Lewis Publishers, Boca Raton, pp. 19-60.

Aravind, P., Prasad, N.V., 2003. Zinc alleviates cadmium-induced oxidative stress in Ceratophyllum demersum L.: a free floating freshwater macrophyte. Plant Physiology and Biochemistry 41, 391-397.

Armstrong, D., 2008. Advanced Protocols in Oxidative Stress I. Humana Press, New Jersey, p. 430

Baker, A.J.M., Brooks, R.R., 1989. Terrestrial higher plants which hyperaccumulate metallic elements: a review of their distribution, ecology and phytochemistry. Biorecovery 1, 81-126.

Baryla, A., Laborde, C., Montillet, J.L., Triantaphylides, C., Chagvardieff, P., 2000. Evaluation of lipid peroxidation as a toxicity bioassay for plants exposed to copper. Environmental Pollution 109, 131-135.

Benton Jones Jr., 2001. Laboratory Guide for Conducting Soil Tests and Plant Analysis. CRC Press, New York, p. 363.

Bini C., in press. Environmental impact of abandoned mine waste: a review. Nova Scince Publishers, Hauppauge, New York, pp. 50.

Bini, C., Maleci, L., Romanin, A., 2008. The chromium issues in soils of the leather tannery district in Italy. Journal of Geochemical Exploration 96, 194-202.

Bini, C., Fontana, S., Wahsha, M., 2010. Soil contamination by mine dumps, plant toxicity and restoration perspectives by phytoremediation. In: Gilbert, D., Pattee, E., Vianello, G., Antisari, L.V. (Eds.), Air, water, and soil pollution: Environmental Quality, vol. 4, pp.173-180. Geol@b onlus, Imola.

Bradl, H.B. 2005. Heavy Metals in the Environment, 1st ed. Elsevier, Amsterdam.

Campana, R., Galuppo, A., Mastellone, F., Spagna, V., Toffoletto, F., Zanco, A., 2007. Percorsi geologico-ambientali in Valle del Mis e Valle Imperina (provincia di Belluno) Progetto Interreg IIIC sud- Resnafront. Regione del Veneto, Unione Europea.

D.L. Decreto Legislativo 152/2006 Gazzetta Ufficiale n.88 del 14/04/2006 - S.O. n.96.

Delgado, J., Sarmiento, A.M., Condesso De Melo, M.T., Nieto, J.M., 2009. Environmental impact of mining activities in the southern sector of the Guadiana Basin (SW of the Iberian Peninsula). Water, Air, and Soil Pollution 199, 323-341.

Dissegna, M., Marchetti, M., Vannicelli, C.L., 1997. I sistemi di terre nei paesaggi forestali del Veneto. Regione del Veneto, Dipartimento per le foreste e l'economia montana. Multigraf, Spinea, p. 151.

Fontana, S., Wahsha, M., Bini, C., 2010. Preliminary observations on heavy metal contamination in soils and plants of an abandoned mine in Imperina Valley (Italy). Agrochimica 54 (4), 218-231.

Frizzo, P., Ferrara, E., 1994. I giacimenti a solfuri massivi del distretto agordino-valsuganese (Basamento Sudalpino). Alpi Orientali. Giornata di studio in ricordo del Prof. Stefano Zucchetti, Torino, pp. 147-154.

Genevini, P.L., Manstretta, M., Mecella, G., 1994. Tessitura. Ministero delle Risorse Agricole, Alimentari e Forestali, Osservatorio Nazionale Pedologico e per la Qualità del Suolo. Metodi ufficiali di analisi chimica del suolo, Roma, pp. 41-57.

Gessa, C., Ciavatta, C., 2000. XIII. Complesso di scambio. In: Violante, P. (Ed.), Metodi di analisi chimica del suolo. Ministero per le Politiche Agricole e Forestali, Osservatorio Nazionale Pedologico e per la Qualità del Suolo. Franco Angeli Editore, Milano.

Giordano, D., 2008. Dolomiti di Cristallo - Minerali e Mineralogia nell'Agordino. GAMP Dolomiti. Grafiche Antiga Crocetta del Montello (TV).

Gobert, M., Gruffat, D., Habeanu, M., Parafita, E., Bauchart, D., Durand, D., 2010. Plant extracts combined with vitamin $E$ in PUFA-rich diets of cull cows protect processed beef against lipid oxidation. Meat Science 85, 676-683.

Greger, M., Landberg, T., 2003. Improving removal of metals from soil by Salix. Proc. VII ICOBTE, vol. 1, II, pp. 146-147.

Heath, R.L., Packer, L., 1968. Photoperoxidation in isolated chloroplasts. I. Kinetic and stoichiometry of fatty acid peroxidation. Archives of Biochemistry and Biophysics 125, 189-198.

Hood, T.M., Benton Jones Jr., J., 1997. Soil and Plant Analysis in Sustainable Agriculture and Environment. Marcel Dekker, Inc., New York, p. 877.

Jones, B., 2001. Laboratory Guide for Conducting Soil Tests and Plant Analysis. CRC Press, Boca Raton, p. 363.

Joshi, G., Sultana, R., Tangpong, J., Cole, M.P., Clair, D., Vore, M., Estus, S., Butterfield, D.A., 2005. Free radical mediated oxidative stress and toxic side effects in brain induced by the anti cancer drug adriamycin: insight into chemobrain. Free Radical Research 39 (11), 1147-1154.

Kabata-Pendias, A., 2001. Soil-plant transfer of trace elements - an environmental issue. Geoderma 122, 143-149.

Kabata-Pendias, A., 2011. Trace Elements in Soils and Plants, 4th ed. CRC Press, Boca Raton, p. 548.
Katoch, B., Begum, R.,2003. Biochemical basis of the high resistance to oxidative stress in Dictyostelium discoideum. Indian Academy of Sciences 28 (5), 581-588.

Królak, E., 2003. Accumulation of $\mathrm{Zn}, \mathrm{Cu}, \mathrm{Pb}$ and $\mathrm{Cd}$ by Dandelion (Taraxacum officinale Web.) in environments with various degrees of metallic contamination. Polish Journal of Environmental Studies 12 (6), 713-721.

Kuzovkina, Y.A., Knee, M., Quigley, M.F., 2004. Cadmium and copper uptake and translocation of five Salix L. species. International Journal of Phytoremediation 6 (3), 269-287.

Leita, L., Petruzzelli, G., 2000. XI. Metalli Pesanti. In: Violante, P. (Ed.), Metodi di analisi chimica del suolo. Ministero per le Politiche Agricole e Forestali, Osservatorio Nazionale Pedologico e per la Qualità del Suolo. Franco Angeli Editore, Milano.

Lim, H.S., Lee, J.S., Chon, H.T., Sager, M., 2008. Heavy metal contamination and health risk assessment in the vicinity of the abandoned Songcheon Au-Ag mine in Korea. Journal of Geochemical Exploration 96, 223-230.

Loureiro, S., Santos, C., Pinto, G., Costa, A., Monteiro, M., Nogueira, A.J.A., Soares, A., 2006. Toxicity assessment of two soils from Jales mine (Portugal) Using Plants: growth and biochemical parameters. Archives of Environmental Contamination and Toxicology 50, 182-190.

Margesin, R., Schinner, F., 2005. Manual for Soil Analysis - Monitoring and Assessing Soil Bioremediation, 1st ed. Springer, Heidelberg, Germany, pp. 359.

Mikulka, J., Korčáková, M., Burešová, V., Andr, J., 2009. Changes in weed species spectrum of perennial weeds on arable land, meadows and pastures. Plant Protection Science 45, 63-66.

Mukherjee, P.K. Ahamed, K.N., Kumar, V. Mukherjee, K. Houghton, PJ. 2007. Protec tive effect of biflavones from Araucaria bidwillii Hook in rat cerebral ischemia/ reperfusion induced oxidative stress. Behavioural Brain Research 178, 221-228.

Pignatti, S., 1982. Flora d'Italia. Edagricole, Bologna, pp. 1-3.

Savinov, A.B., Kurganova, L.N., Shekunov, Y.I., 2007. Lipid peroxidation rates in Taraxacum officinale Wigg. and Vicia cracca L. from biotopes with different levels of soil pollution with heavy metals. Russian Journal of Ecology 38 (3), 174-180.

Simon, L., Martin, H.W., Adriano, D.C., 1996. Chicory (Cichorium intybus L.) and dandelion (Taraxacum officinale Web.) as phytoindicators of cadmium contamination. Water, Air, and Soil Pollution 91 (3-4), 351-362.

Sinha, S., Saxena, R., Singh, S., 2005. Chromium induced lipid peroxidation in the plants of Pistia stratiotes L.: role of antioxidants and antioxidant enzymes. Chemosphere 58, 595-604.

Soffler, C., 2007. Oxidative stress. The Veterinary Clinics of North America. Equine Practice 23 (1), 135-157.

Soil Survey Staff, 1999. Soil taxonomy. A basic system of soil classification for making and interpreting soil surveys, 2nd ed. USDA Natural Resources Conservation Service Agricultural Handbook, vol. 436. US Gov. Printing Office, Washington, DC.

Taulavuori, E., Hellström, E., Taulavuori, K., Laine, K., 2001. Comparison of two methods used to analyse lipid peroxidation from Vaccinium myrtillus (L.) during snow removal, reacclimation and cold acclimation. Journal of Experimental Botany 52 (365), $2375-2380$.

Timbrell, J., 2009. Principles of Biochemical Toxicology, 4th ed. Informa Healthcare USA, Inc., New York

Verma, S., Dubey, R.S., 2003. Lead toxicity induces lipid peroxidation and alters the activities of antioxidant enzymes in growing rice plants. Plant Science 164, 645-655

Violante, P., Adamo, P., 2000. III. Reazione. In: Violante, P. (Ed.), Metodi di analisi chimica del suolo. Ministero per le Politiche Agricole e Forestali, Osservatorio Nazionale Pedologico e per la Qualità del Suolo. Franco Angeli Editore, Milano.

Wahsha, M., Al-Jassabi, S., 2009. The role of Silymarin in the protection of mice liver damage against Microcystin-LR toxicity. Jordan Journal of Biological Sciences 2 (2), 63-68.

Wahsha, M., Al-Jassabi, S., Azirun, M., Abdul-Aziz, K., 2010. Biochemical screening of Hesperidin and Naringin against liver damage in Balb/c mice exposed to MicrocystinLR. Middle East Journal of Scientific Research 6 (4), 354-359.

Walkley, A., Black, I.A., 1934. An examination of the Degtjareff method for determining soil organic matter, and proposed modification of the chromic acid titration method. Soil Science 37, 29-38.

Yadav, S.K., 2010. Heavy metals toxicity in plants: an overview on the role of glutathione and phytochelatins in heavy metal stress tolerance of plants. South African Journal of Botany 76 (2), 167-179.

Zang, W., Yong, C., Tu, C., Ma, Q., 2002. Arsenic speciation and distribution in arsenic hyperaccumulating plant. The Science of the Total Environment 300, 167-177.

Zielinska, M., Kostrzewa, A., Ignatowicz, E., Budzianowski, J., 2001. The flavonoids, quercetin and isorhamnetin 3-O-acylglucosides diminish neutrophil oxidative metabolism and lipid peroxidation. Acta Biochimica Polonica 48 (1), 183-189. 